\title{
Effects of Mango Mistletoe (Dendrophthoe pentandra L. Miq) Extracts on Brain in Hypertensive Rats Treated with Deoxycorticosterone Acetate (DOCA)-Salt
}

\author{
Syntia Diyah Hayu Ria Saputri ${ }^{1}$, Nour Athiroh Abdoes Sjakoer ${ }^{1 *}$, Nurul Jadid Mubarakati ${ }^{1}$ \\ ${ }^{1}$ Department of Biology, Faculty of Mathematics and Natural Sciences, Universitas Islam Malang, J1. MT. Haryono 193, Malang
}

Submission: January 2021; Revised: January 2021; Accepted: March 2021

*Corresponding author: Nour Athiroh Abdoes Sjakoer; e-mail: nour.athiroh@ @nisma.ac.id; tel.: +62-85710605882

\begin{abstract}
Mango mistletoe (Dendrophthoe pentandra) is a plant that has the potential as a medicinal plant. Mango mistletoe is reported to contain the flavonoids quercetin, mesoinositol, rutin, and tannins. Hypertension as a noncommunicable disease is a very serious health problem experienced by people in developing countries. Hypertension can be caused by high ROS (reactive oxygen species) which can inhibit oxygen flow to the heart and brain. Antioxidants can reduce the risk of hypertension. Damage to the brain due to hypertension is manifest in the white matter area. This study aimed to see how the histopathological profile of the brain in hypertensive rats (DOCA-Salt) which were given mango mistletoe methanolic extract (MMME) by experimental method. The number of tested animals were 25 male Wistar rats divided into 5 groups, each group contained 5 rats, they were negative control (Control-) as normotension, positive control (Control+) as inducer, and the treatment group with the provision of MMME at a dose of $50 \mathrm{mg} /$ $\mathrm{kgBW}, 100 \mathrm{mg} / \mathrm{kgBW}$, and $200 \mathrm{mg} / \mathrm{kgBW}$. Data were analyzed using JAMOVI 1.1.9.0. Based on the results of the study showed that the difference in significant values between all groups was $p<0.05$. Therapy with EMBM to male rats significantly can decrease the number of cell necrosis and affect the width of the white matter area of the brain. The three dose variations did not show a significant difference, so this effect was controlled by the MMME dose of 50 mg / $K g B W$ which was the optimum dose in reducing the amount of cell necrosis in the white matter area of the male Wistar rats brain
\end{abstract}

Keywords: DOCA-Salt, Hypertension, Mango Mistletoe, White Matter Area

\section{INTRODUCTION}

Hypertension is one of the non-communicable diseases with high prevalence and a major risk factor for cardiovascular disease and other complications, along with technological advances in developing countries such as Indonesia which tend to adopt unhealthy lifestyles [1]. World Health Organization (WHO) has estimated that by 2020, non-communicable diseases will cause $73 \%$ of deaths and $60 \%$ of all morbidity in the world. It is estimated that the countries most affected are developing countries, including Indonesia [2].

The factors that cause hypertension can be triggered by high ROS (Reactive Oxygen Species) which can inhibit oxygen flow to the heart and brain. In addition, another factor that causes hypertension is lipid oxidation which causes atherosclerosis or blockage of the arteries. Atherosclerosis is triggered by untreated oxidation of LDL which can lead to an increase in blood pressure [3]. One of the organs that plays a role in blood pressure regulation is the brain [4]. In addition, the brain is an organ with a high fat content $( \pm 80 \%)$ so it is susceptible to free radical attack [5]. Blockage of the arteries (atherosclerosis) in the brain will also cause dysfunction in endothelial (pro-necrotic) cells as a result, causing tissue remodeling around the blood vessels. In the brain, the manifestations can be in the white matter (white substance). Thus, it will inhibit the performance of the brain due to obstruction of the flow of oxygen to the brain.

An alternative to preventing the risk of this disease can be done by consuming antioxidants as an effort to have a healthy lifestyle. Antioxidants can reduce the risk of hypertension [3]. Secondary metabolites that can be found in vegetable, fruit, plants, and other have a role as an anti-cancer, anti-allergic, antioxidant, anti-inflammatory, and inhibitor of certain enzymes [4]. Many natural sources of antioxidants are found in one of which is the mango mistletoe (Dendrophthoe pentandra L. Miq). The use of herbal ingredients to support public health in line with the back to nature lifestyle is a current trend. It is also triggered because natural ingredients have fewer side effects, are easy to obtain, and are more economical than chemical drugs [6].

Mango mistletoe is reported to contain the flavonoids quercetin, mesoinositol, rutine, and tannins [7]. Based on an in vivo research, mangoe mistletoe is able to repair endothelial damage resulting in normal endothelial function returning, so that albumin levels become normal [8]. The ethanol fraction of the mango mistletoe was able to improve colon tissue abnormalities as indicated by the absence of dysplasia in the treatment of the ethanol fraction of mango mistletoe $0.250 \mathrm{mg} /$ gram BW and $0.500 \mathrm{mg} /$ gram BW. Mango mistletoe has the potential as an anti-colon cancer 
agent [9]. Based on the subchronic toxicity test for 28 days, mango mistletoe combined with tea mistletoe are not toxic to kidney function [10]. The flavonoids and tannins contained in mango mistletoe are also thought to act as antihypertensives, with their ability to reduce Vascular System Resistance (SVR) because they cause vasodilation and also affect the action of Angiotensin Converting Enzyme (ACE) which can inhibit the change of angiotensin $I$ to angiotensin II [11].

\section{METHODS}

This study is a true experimental design using a completely randomized design (CRD), using experimental animals male Wistar strain mice (Rattus novergicus) aged $6-8$ weeks and weighing 100-200 grams consists 25 rats. This study has received the approval of the Health Research Ethics Commission of the Faculty of Medicine, Islamic University of Malang (Ethical Clearence) with number: 006/LE.001/IV/03/2020. The experimental animals were divided into five groups, namely: the normal control group (Control-) (normotension), the treatment control group (Control+) (hypertension), and the treatment group that was given methanolic extract of mango mistletoe at a dose of $50 \mathrm{mg} / \mathrm{kgBW}$, $100 \mathrm{mg} / \mathrm{kgBW}$, and $200 \mathrm{mg} / \mathrm{KgBW}$. The research was conducted at the Ecology Laboratory of the Faculty of Mathematics and Natural Sciences, Islamic University of Malang, the Laboratory of the Faculty of Medicine, Islamic University of Malang, the Physiology Laboratory of the Faculty of Medicine, Brawijaya University Malang, the Laboratory of Anatomical Histopathology, the Faculty of Medicine, Brawijaya University Malang and the Laboratory of Balai Materia Medica Batu, East Java.

\section{Preparation of Mango Mistletoe Methanolic Extract (MMME)}

The leaves of the mango mistletoe used have been selected, namely the leaves were not rotten, separated from the leaf bones and clean. The leaves were dried by oven at a temperature of 50$60{ }^{\circ} \mathrm{C}$ until the water content was reduced, then the mango mistletoe leaves are crushed and blended to form simplicia. Then proceed with the maceration process. Simplicia was weighed 100 grams and then put into a 1.5 liter plastic bottle. After that, 1 liter of $90 \%$ methanol solution was added and matched for 1 hour until the solution was homogeneous. After 1 hour, then it was allowed to stand for 24 hours, the active substance in the mango mistletoe leaves can be withdrawn by the methanol solvent. Remaceration was carried out 3 times, after which obtained supernatant was then made into an extract by evaporation using a rotary evaporator. The purpose of evaporation was to evaporate the solvent, hence, a concentrated liquid solution was obtained with a higher concentration.

\section{Maintenance of Experimental Animals}

The male wistar rats (Rattus norvegicus) was acclimatized in the Ecology Laboratory of the Faculty of Mathematics and Natural Sciences, Islamic University of Malang for seven days with a room temperature of $\pm 25^{\circ} \mathrm{C}$ with a humidity of $\pm 50-60 \%$.

\section{Experimental Animals Surgery}

Rats were induced with DOCA in all treatments except the normal control group (Control-) (normotension) subcutaneously at a dose of $15 \mathrm{mg} / \mathrm{KgBW}$ dissolved in corn oil and $2 \% \mathrm{NaCl}$ given sonde and drinking water. DOCA was given twice a week for 4 weeks.

\section{Histopathological Examination}

The rats were sedated by injection of ketamine then performed surgery and brain organs were taken. After that, careful macropatological observations were made for each organ. Brain organs are weighed to obtain absolute weight. While the data analyzed is relative weight, namely absolute organ weight divided by body weight [12]. The separated brain organs were immediately preserved in a $10 \%$ formalin solution until all parts of the organs were immersed and histopathological preparations were made by means of the organs being cut and multilevel washing using xylol, 70\% alcohol, $80 \%$ alcohol, and $95 \%$ alcohol. Then the organ was compacted with paraffin and cut with a microtome. Then the organ was attached to the glass into a histopathological slide with the H\&E (Hematoxylin\&Eosin) staining technique and then observed under a trinocular microscope Olympus U-TV0.5XC-3, T7 Tokyo, Japan with 400x magnification so that the cells experiencing necrosis on the white matter area can be seen clearly. The examination of the width of the white matter area was carried out by microscopic observation with a 200x magnification, then measured by the ImageJ application. The width of the white matter area is expressed in micrometer $(\mu \mathrm{m})$.

\section{Analysis Data}

The data obtained were tabulated according to groups, then statistical tests were carried out using 
the Jamovi application version 1.1.9.0. The mean (mean) and standard deviation (Standard Deviation) was calculated for each treatment. Significant differences between the means were analyzed using the statistical one-way analysis of variance (ANOVA) method, with a 95\% confidence level, then proceed with the Tukey Post Hoct Test. The results were considered significant if $\mathrm{p}$-value $<0.05$.

\section{RESULTS AND DISCUSSIONS}

\section{Histopathological Observation of White Matter Necrosis}

The histopathological profile of the brain in the white matter area of male Wistar rats (Rattus norvegicus) which had been given mango mistletoe methanolic extract (Dendrophthoe pentandra) for 14 days was assessed based on the number of neuron cell damage contained in the white matter of male Wistar rats. The results were tabulated based on the treatment of each group is presented in the form of a picture as follows (Figures 1 and 2).

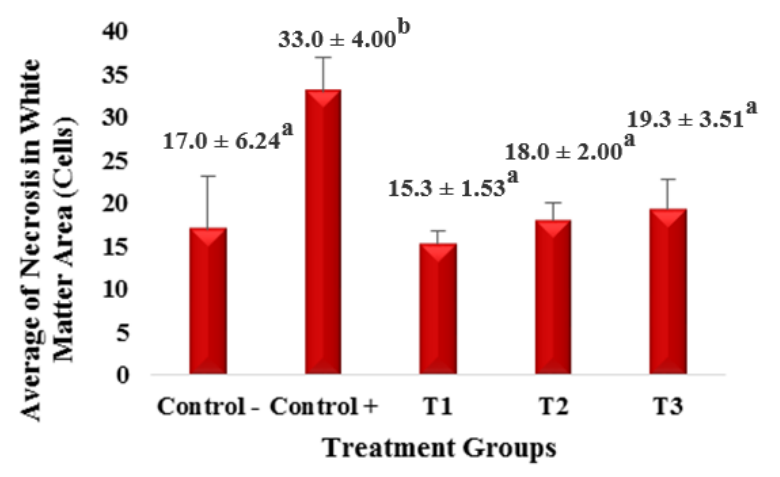

Figure 1. Average Brain Cell Damage (Necrosis) in Male Wistar Rats in White Matter Area after Giving Mango Mistletoe Methanolic Extract (MMME) for 14 Days. Results are mean \pm SEM. The difference in a and $\mathrm{b}$ notation showed significant differences $(\mathrm{p}<0.05)$ that occurred between the treatment groups. Control (-), Normal control group (without administration of DOCA and salt and mango mistletoe methanol extract), Control (+) was The control group was treated with $15 \mathrm{mg} /$ $\mathrm{KgBW}$ of DOCA and salt without the mango mistletoe methanol extract, T1 was treatment group with DOCA $15 \mathrm{mg} / \mathrm{KgBW}$ and salt, mango mistletoe methanol extract (EMBM) dose of $50 \mathrm{mg} / \mathrm{KgBB}$, T2 was treatment group with DOCA $15 \mathrm{mg} / \mathrm{KgBW}$ and salt, mango mistletoe methanol extract (EMBM) dose $100 \mathrm{mg} / \mathrm{KgBW}$, T3 was treatment group with DOCA $15 \mathrm{mg} / \mathrm{KgBW}$ and salt, mango mistletoe methanol extract (EMBM) dose $200 \mathrm{mg} / \mathrm{KgBW}$.

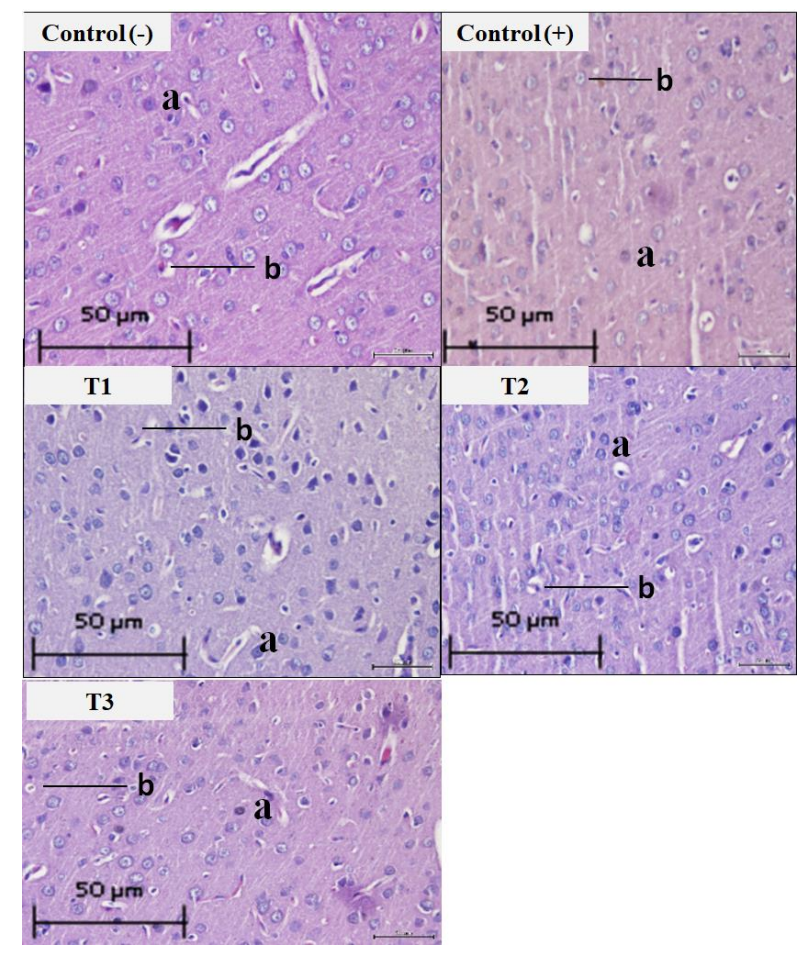

Figure 2. Histopathological Overview of the Brain (white matter) of Hypertensive Rats (DOCASalt) Exposed to MMME for 14 Days. a) Normal Cell, b). Cell Damage (Necrosis).

\section{Measuring the Width of the White Matter Area Using the ImageJ Application}

The width of the white matter area was carried out by microscopic observation at 200x magnification, then measured by the ImageJ application. The width of the white matter area is expressed in micrometer $(\mu \mathrm{m})$, the results are tabulated based on the treatment of each group which is presented in the following figure (Figures 3 and 4).

Figure 3 showed that the mean area of white matter in the brain in the positive control group (Control+), namely rats induced by DOCA-salt without MMME, shows the lowest mean of 3.25 $\mu \mathrm{m}$, when compared to the negative control group (Control-) or without DOCA-salt induction is 3.44 $\mu \mathrm{m}$. In group (T1), namely the DOCA-salt treatment group which was then given MMME at a dose of $50 \mathrm{mg} / \mathrm{KgBW}$ for 14 days experienced an increase in the mean width of white matter by $3.80 \mu \mathrm{m}$ compared to the positive control group (Control+). The three dose variations did not show a significant difference in mean white matter width and had the same potential to reduce the reduction in white matter width in the male Wistar rat brain. 


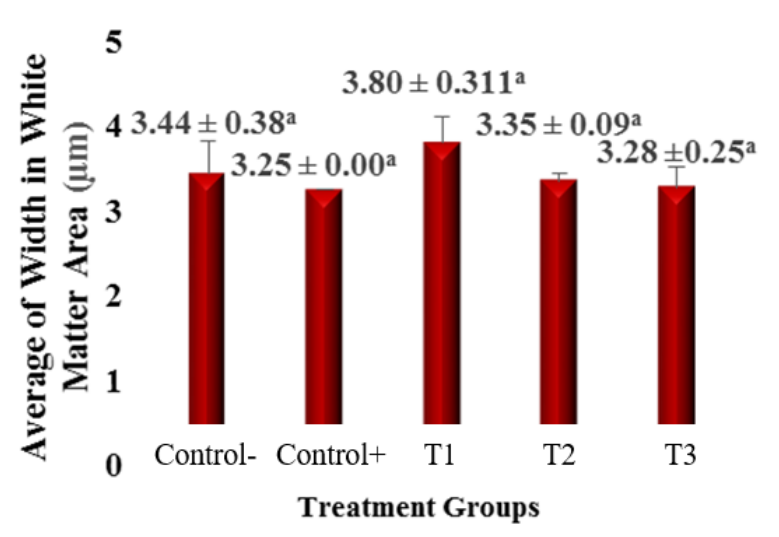

Figure 3. Average of Measurement Results for the Width of the White Matter Area after Giving Mango Mistletoe Methanolic Extract (MMME) for 14 Days.
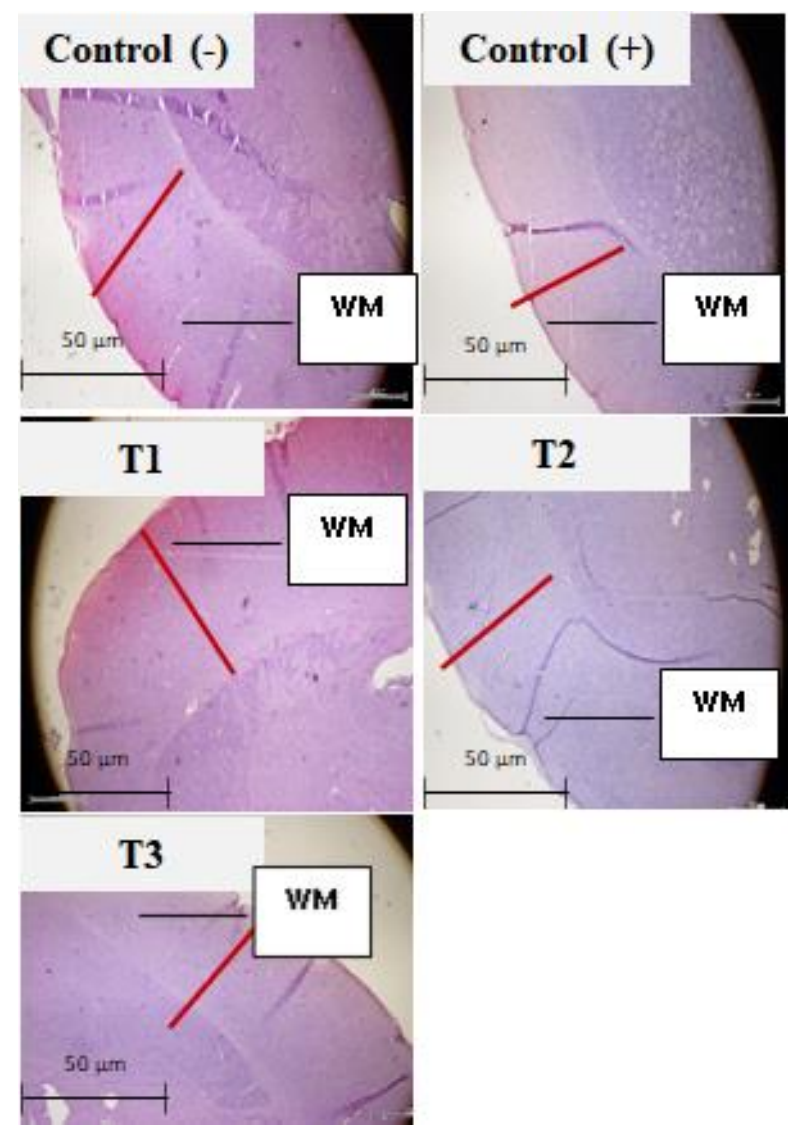

Figure 4. White Matter Microanatomy Area After 14 Days EMBM Giving (Olympus UTV0.5XC-3 Trinocular Microscope, T7 Tokyo, Japan) 200x Magnification, Hematoxylin-Eosin (H\&E) Staining. WM = White Matter.

Figure 4 showed that staining with Hematoxylin and Eosin (H\&E) shows that the width of the white matter area in the positive control group (Control+) looks narrower than the DOCA-salt induction group in the negative control (Control-). The therapy of mango mistletoe methanolic extract (MMME) in hypertensive rats significantly affected the amount of necrosis of white matter cells. This is evidenced by the pvalue $=0.001$ in the ANOVA test, where the calculated $p$-value is less than $0.05(\mathrm{p}<0.05)$. The results of the study based on the histogram (Figure 1) of the effect of DOCA-salt induced in the positive contour (Control+) group showed that DOCA-salt induction was able to significantly increase the amount of necrosis of brain cells in the white matter area $(\mathrm{p}<0.05)$ compared to the group without induction. DOCA and salt.

The effect of DOCA-salt induction also had no significant effect $(\mathrm{p}>0.05)$ on the width of the white matter area as shown in Figure 3, where the positive control group (Control+) showed a smaller mean white matter width with a mean of 3.25 in comparison. negative control group (Control-) with a mean of 3.44. This proves that DOCA-salt induction can affect the width of white matter. White matter lesions have been reported to be associated with cardiovascular events such as hypertension, changes in white matter are closely associated with worsening appearance in people with hypertension. Longstanding hypertension results in hypoperfusion of brain tissue, resulting in ischemic damage to the white matter in the subcortex, known as leukoaraisosis. This condition is a common complication of hypertension associated with microvascular damage and contributes to the risk of stroke and dementia [13]. DOCA-salt exposure is recognized to increase blood pressure or hypertension in mice, there is activity to increase the reabsorption of DOCA-salt and water causing the blood volume to increase thereby increasing blood pressure. Sodium reabsorption can lead to increased water reabsorption and increased blood pressure. There is an increase in vasopressin causing water retention and vasoconstriction [4].

The results of histopathological examination showed that in the $\mathrm{T} 1$ group, namely the $50 \mathrm{mg} /$ KgBW MMME dose, there was an improvement in the histological profile which was marked by the reduction in necrosis of cells. This can be indicated by the mean value of the T1, T2 and T3 groups smaller than the positive control group induced by DOCA-salt. This is thought to be due to the activity of secondary metabolite compounds contained in mango mistletoe, namely flavonoids which are widely reported as potential antioxidants. Flavonoids have an effect as antioxidants and can prevent oxidation in the initiation and propagation phases. At the initiation stage, quercetin is able to stabilize free radicals formed by oxygen radical compounds, peroxide and superoxide. Quersein stabilizes these compounds through hydrogenation reactions and complex formation [6]. Antioxidant of flavonoid compounds can donate hydrogen to free radicals 
so that it can stabilize low-energy free radicals that come from flavonoid compounds that lose hydrogen atoms [14].

Normal cells have a number of defense enzymes that act as endogenous antioxidants to detoxify free radicals and prevent cell damage. The susceptibility of a tissue to oxidative damage depends on its oxidative defense mechanisms, among others by the activity and content of endogenous antioxidant enzymes. The increase in free radicals in the body will increase the use of intracellular antioxidant enzymes, causing a decrease in the activity of the SOD enzyme as an endogenous antioxidant system in the body [14]. So that the body needs an external or exogenous defense system that can be obtained from foods rich in antioxidants which will later protect cells from damage or necrosis.

Necrosis is irreversible cell damage caused by prolonged ATP deficiency and lipid peroxidation due to increased ROS. The macroscopic picture of necrosis is in the form of small dark cells (picnotic), fragmentation of the cell nucleus into several parts (carioreksis) and the cell nucleus disappears (karyolysis). This figure is partly due to increased eosin binding to denatured intracytoplasmic proteins, and partly to the loss of basophils normally obtained from RNA in the cytoplasm. When enzymes have degraded organelles, the cytoplasm becomes vacuole. Finally, there can be a classification of dead cells. Nuclear changes provide one of three patterns, all of which are due to the nonspecific breakdown of NA. The first pattern is cariolysis, which is the loss of DNA by the activation of the endonuclease enzyme caused by $\mathrm{Ca}^{2+}$ influx, the cell nucleus will look more basophilic and chromatin fading occurs. The second pattern is pycnosis, characterized by the shrinkage of the cell nucleus and it looks more basophilic then the chromatin condenses into a dense mass caused by changes in cell $\mathrm{pH}$. The third pattern is cariorexis, in which the picnotic nucleus undergoes fragmentation into several clumped chromatin and after that it disappears. Within 1-2 days, this in the dead cells completely disappears. Cells that experience necrosis can no longer return to normal and will experience death [15].

Oxidative stress caused by an imbalance between antioxidants and the production of oxidants, including ROS, is known to contribute to the degenerative process [16]. ROS is a relatively high oxidant molecule, is very unstable so it quickly reacts in front of other molecules. ROS occurs both endogenously and exogenously, through regular metabolite activity, lifestyle activities and diet. Conditions where free radical levels are higher than antioxidant levels which can cause oxidative stress can increase neuronal cell damage [17], an increase in ROS can cause a decrease in neuronal cell viability due to inhibition of the electron transport chain and formation of ATP. This causes the mitochondria to lack ATP so that in the end there will be cell death [18].

In this results the negative control group (Control-) where without DOCA-salt induction, necrosis was still found which had a mean of 17.0 \pm 6.24 . The control group ranged from $36 \pm 1.71$, this means that the experimental animals were in good health even though it was possible that there was still degeneration and necrosis of the neurons even without the induction of exogenous substances [19].

The three variations of dose did not show a significant difference $(p>0.05)$, this was due to a desensitizing effect due to decreased receptor sensitivity due to repeated or excessive dose exposure, so that it has the same potential in reducing necrosis in the white matter area of the brain and the optimum MMME dose in this study is $50 \mathrm{mg} / \mathrm{KgBW}$.

\section{CONCLUSION}

Mango mistletoe methanolic extract when treated to hypertensive rats (Rattus novergicus) were exposed for 14 days at doses of $50 \mathrm{mg} / \mathrm{KgBW}$, $100 \mathrm{mg} / \mathrm{KgBW}$, and $200 \mathrm{mg} / \mathrm{KgBW}$ was effected to number of cell necrosis and width of the white matter area of the brain, significantly. The three dose variations did not show a significant difference, so this effect was controlled by the MMME dose of $50 \mathrm{mg} / \mathrm{KgBW}$ which was the optimum dose in reducing the amount of cell necrosis in the white matter area of the male Wistar rat brain.

\section{ACKNOWLEDGEMENT}

Thanks are given to LLDIKTI 7 - RISBANG Number: 187 / SP2H / LT / DRPM / 2020 on 9 March 2020. PT - LLDIKTI 7 Number: 017 / SP2H / LT -MULTI / LL7 / 2020 on 17 March 2020. Researcher-LPPM Number : 199 / G164 /U.LPPM/K/B.07/VIII/2020 on 7 August 2020..

\section{REFERENCES}

1. Singh S., R Shankar and GP Singh. 2017. Prevalence and associated risk factors of hypertension: a cross-sectional study in urban varanasi. International Journal of Hypertension. 2017:1 -10.

2. Ekowati, R dan T, Sulistyowati. 2009. Prevalence of hypertension and its 
determinants in Indonesia. Journal of Indonesian Medical Association. 59(12).

3. Arrosyadi, U L., Y D P Astutik., H A Pradana., A C Islamianti dan S Marfuah. 2016. Antioxidant activity and antihypertensive effect of low caffeine with antioxidants as a functional beverage. Faculty of Agricultural Technology, University of Jember.

4. Athiroh, N dan N, Permatasari. 2011. Mechanism of Deoxycorticosterone Acetate (DOCA)-salt to increase blood pressure in experimental animals. El-Hayah. 1(4):199 213.

5. Utami, P. 2003. Medicinal Plant to Treat Diabetes Melitus. Jakarta : Agromedia Pustaka.

6. Nisa, Z., Y, Purnomo dan D, Andriana. 2013. The effect of tea mistletoe methanolic extract (Scurulla atropurpurea B1. Danser) on the number of blood vessel endothelin-1 in the brain of rats with induced by DOCA (Deoxycorticosterone Acetate) and salt. Faculty of Medical, Islamic University of Malang.

7. Kurniasih N., Kusmiyati M., Nurhasanah, Sari R.P. and Wafdan R. 2015. Potential of soursop leaves (Annona muricata Linn), binahong leaves (Anredera cordifolia (Ten) Steenis), and mango mistletoe leaves (Dendrophthoe pentandra) as cancer-preventing antioxidants. Department of Pharmacy, Bandung Health Polytechnic.

8. Pramudanti, D R., M. C. Padaga dan D, Winarso. 2012. The effect of manggo mistletoe (Dendrophthoe pentandra) water extract therapy on albumin levels and the kidney histopathological profile of animal models in hypercholesterolemia condition. Department of Veterinary Education, University of Brawijaya Malang.

9. Wicaksono, M H B dan S, Permana. 2013. Potential ethanol fraction of mango mistletoe (Dendrophthoe pentandra) as agent anticancer of colon in mice (Mus musculus Balb/c) after induced by Dextran Sulvat (DSS) dan Azoxymethane (AOM). Journal of Tropical Biology. 1(2): 75 - 79.

10. Anjani, M., N, A,A, Sjakoer and N, J, Mubarakati. 2021. Study of subchronic during 28 days: toxicity test of methanolic extract combination of Scurulla atropurpurea and Dendrophthoe pentandra against malfunctioning kidney function of female wistar rats. Biosciencetropic. 6(2):58-63.

11. Umayasari, e., Inandha L V dan Rahayu M P. 2015. Antihypertensive activity of dewandaru leaves (Eugenia uniflora L.) ethanol extract in male white rats induced by adrenalin. Indonesian Pharmacy Journal. 12(1):1-6.
12. Mihmidati, L dan Athiroh, N. 2017. The effect of tea mistletoe methanolic extract Pengaruh (Scurrula atropurpurea (B1.) Dans) given subchronic 90 days to female rats on brain necrosis. Biosciencetropic. 3(2):16 - 23.

13. Amir, D. 2010. Impaired motoric function in patients with hypertension (Biomoleculer Studies). Neurona. 28(1).

14. Astuti, S. 2008. Soy isoflavones and their potential as free radical scavengers. Journal od Industrial Technology and Agricultural Products. 13(2):126 - 136.

15. Amiralevi, S H., H F, Trianto., V, Novianty and M, Zakiah. 2017. Effects of acute formaldehyde exposure on liver histology of male Wistar rats. Journal of Cerebellum. 3(3):874 - 887.

16. Fitria,L., M, H Widyananda and S P, Sakti. 2019. Analysis of Allopurinol, Cucurbitacin B, Morindine, and Piperine as Xanthine Oxidase Inhibitor by Molecular Docking. Journal of Smart Bioprospecting and Technology (JSMARTech). 1(1):6 - 11.

17. Ningsih, HU. 2018. The Effect of giving ajwa palm extract on the number of neurons in embryo of mice (Mus musculus). Department of Biology, Faculty of Science and Technology, Islamic State University of Sunan Ampel Surabaya.

18. Perkasa, A. 2016. The effect of oplosan liquor on histopathological changes in the brain of male wistar rats. Faculty of Medical, University of Jember.

19. Islamiyah, A., U, Susilowati dan Lestari. 2015. The effect of ettawa goat milk on the intelligence of male Balb $\mathrm{C}$ mice (Mus musculus). Department of Biology State University of Malang. 